\title{
KEARIFAN TRADISI ISLAM \\ DALAM PENGELOLAAN AIR
}

\author{
Alfalisyado \\ STAIN Purwokerto \\ Jl. A. Yani 40 A (+62-81) 635624 Purwokerto 53126 \\ E-mail: muhammad_alfaedison@yahoo.com \\ HP. +62-8576282228
}

Abstract: This article discuss and analyze about concept and characteristic of water in Islam. This concept influences to the social and economic as well. Beside, this article describe about concept of water transformation and changing of society point of view, partly and globally. These data are collected by text and context study, especially by the mix approach, it's culture study and Islamic jurisprudence. The result of this study, there is shifting of understanding in Islamic scholars about concept of water function from al-miyah al-fitrah (water as a natural function) to al-miyāh aliqtiṣādiyyah (commercial water).

Abstrak: Tulisan ini mengulas tentang sifat kepemilikan air dalam perpektif Islam. Konsep kepemilikan juga sangat berpengaruh terhadap dinamisasi sosio-ekonomi yang ada. Selain itu, tulisan ini juga mengulas mengenai transformasi air atas perubahan pola fikir masyarakat, baik lokal maupun global dari segi pemanfaatan. Data-data dikumpulkan melalui kajian teks dan konteks dengan pendekatan campuran, yakni kebudayaan dan uṣl alfiqh. Artikel ini menujukkan adanya pergeseran pemahaman tentang fungsi air dari al-miyah al-fițrah (air sebagaimana fitrahnya) menuju al-miyāh al-iqtișādiyyah (air komersial). Pada tahap al-miyah al-fițrah, air lebih cenderung dipergunakan sebagai sarana ibadah (al-miyāh al-diniyyah) dan kebutuhan hidup lainnya. Seiring dengan kompleksitas ekonomi, terjadi perubahan konsep tentang air dengan memunculkan konsep baru, yaitu air sebagai media komersial atau disebut dengan al-miyāh al-iqtiṣādiyyah.

Kata Kunci: air, mashlāḥah, transformasi, kearifan, tradisi Islam.

\section{A. Pendahuluan}

Misi utama Islam adalah untuk menciptakan kedamaian hidup, yaitu dengan adanya kemaslahat an bagi seluruh makhluk (al-Syātibī, T.Tp: 333). 
Pernyataan ini sering dikenal dengan istilah raḥmatan li al-'ālamīn. Islam menawarkan konsep yang komperehensif dalam berbagai hal, termasuk cara Islam memandang air. Air menjadi salah satu unsur alam yang perlu diperhatikan. Pasalnya, keberlangsungan kehidupan di bumi tak dapat lepas dari peran air. Konsep ketergantungan alam terhadap air ini telah dijelaskan dengan gamblang oleh Islam.

Ada perjalanan unik yang dapat dicermati dari Islam dalam memandang air sebagai unsur alam. Keunikan ini menitikberatkan pada perubahan sifat pemanfaatan dan paradigma masyarakat terhadap air. Salah satu zat yang terbentuk atas kombinasi dua hidrogen dengan satu unsur oksigen ini awalnya dikenal sebagai unsur alam yang sangat melimpah dan tersedia di manapun (Suntana, 2010: 113). Implikasi logisnya adalah hampir saja air dianggap sebagai benda cuma-cuma. Paradigma tersebut menimbulkan efek domino, yaitu mengantarkan kepada kurangnya perhatian terhadap pemanfaatan dan pengelolaan air.

Kealfaan atas pengelolaan air dapat dikatakan dengan tidak mensyukuri nikmat Allah, sekaligus melalaikan tugas manusia sebagai khalïfah. Hal ini terlihat jelas dengan adanya firman Allah dalam Q.S.21:30, yaitu:

"Dan dari air Kami jadikan segala sesuatu yang hidup..."

Air sebagai benda ciptaan Allah yang berlimpah mulai dijadikan objek yang cukup menyita perhatian, mulai dari sisi ilmiah sampai pada bisnis. Berangkat dari air sebagai benda bebas, kemudian menuju pada hasil penelitian seorang guru besar dari Jepang Masaru Emoto tentang keajaiban molekul air sampai dengan fenomena komersialisasi air mineral. ${ }^{1}$ Masalah muncul ketika meneropong pemanfaatan air yang dikorelasikan dengan kepemilikannya (Triono, 2012: 317-338). Pada satu sisi, air merupakan public goods, di sisi lain air menjadi ajang "kapitalisasi sumber daya". Maka itu, perlu adanya pembahasan yang lebih lanjut mengenai konsep kepemilikan air, baik dari sisi doktrin, jenis kepemilikan, teori kepemilikan, serta pemanfaatan kepemilikan atas air.

Tulisan ini mengulas tentang air dari definisi, sifat, dan kepemilikan air sebagai public goods yang berpengaruh terhadap dinamisasi sosio-ekonomi

\footnotetext{
${ }^{1}$ Fenomena awal mula air mineral kemasan memunculkan kontroversi. Namun demikian, seiring berjalannya waktu, kehadiran air minum kemasan menjadi benda yang dibutuhkan oleh masyarakat. Memandang kemaslahat an yang timbul dan manfaat lebih besar daripada mudharat, maka konsep komersialisasi air dipandang boleh.
} 
yang ada. Selain itu, tulisan ini juga mengulas mengenai transformasi air atas perubahan pola pikir masyarakat, baik lokal maupun global dari segi pemanfaatan. Adapun yang menjadi fokus kajian penulisan akan lebih mengerucut pada topik al-miyāh al-iqtiṣādiyyah.

\section{B. Air dan Kepemilikannya dalam Pandangan Islam}

Dari sisi etimologi bahasa Arab, air berasal dari kata al-mā'. Hal itu merupakan bahasa yang digunakan oleh para ahli hukum Islam untuk menyebut air (Suntana, 2010: 113). Dalam pandangan teologi, air terbagi menjadi dua bagian, yaitu pertama air merupakan benda ciptaan Allah SWT, kedua air adalah milik Allah SWT. Air sebagai benda ciptaan (makhluk) dan milik Allah SWT didasarkan pada firman Allah (Q.S.2:284) yaitu:

"Kepunyaan Allah-lah segala apa yang ada di langit dan apa yang ada di bumi..."

Selain itu, juga ditegaskan dalam Q.S.27:60, yaitu:

"Dan yang menurunkan air untukmu dari langit, lalu Kami tumbuhkan dengan air itu kebun-kebun yang berpemandangan indah, yang kamu sekalikali tidak mampu menumbuhkan pohon-pohonnya?"

Dari kedua ayat di atas, air merupakan makhluk dan benda kepunyaan Allah SWT. Air sebagai makhluk adalah pernyataan mutlak yang tidak dapat dielakkan. Namun demikian, air sebagai benda milik Allah perlu adanya penjabaran lebih, di sini terdapat beberapa catatan. Dalam kepemilikan suatu benda, terdapat hak kepemilikan secara mutlak dan kepemilikan nisbi.

Suntana (2010: 126) menjelaskan lebih lanjut mengenai kepemilikan nisbi, yaitu konsekuensi kepemilikan nisbi adanya frekuensi kepemilikan sumberdaya air bersifat sementara dan berkedudukan sebagai benda amanat. Sebagai amanat, sumber daya air memiliki sejumlah implikasi penting. Pertama, sumber daya air diperuntukkan bagi semua orang, bahkan seluruh makhluk. Oleh karena itu, air harus dipergunakan untuk kemaslahat an bersama dan dipergunakan secara adil. Kedua, setiap orang memperoleh suber daya air secara adil. Ketiga, sumber daya air tidak boleh dipergunakan atas otoritas penerima amanat dengan sesuka hati tanpa ada pemikiran yang bijak. Keempat, tidak ada seseorang pun yang punya kewenangan untuk merusak dan memboroskan sumber daya air. Perusakan dan pemborosan harus dihindari dan dicegah.

Al-Qur'an menegaskan bahwa Allah adalah pemilik segala sesuatu. Penegasan ini merupakan landasan ideologis, sekaligus parameter ulama Islam ketika mengartikan kepemilikan. Artinya, Allah adalah sumber dari segala 
kepemilikan, sedangkan manusia merupakan penerima pemberian hak guna kepemilikan (Muhammad dan Alimin, 2004: 135). Hak yang dimiliki manusia terhadap air diatur dalam Islam.

Bagi umat Islam, kepemilikan benda juga mengusung arti konotasi moral. Ini berangkat dari kerangka ideologis yang telah dijelaskan sebelumnya. Sebagai contoh adalah Islam tidak mengakui adanya kepemilikan minuman keras dan zat yang memabukkan yang lainnya. Bukan hanya hal yang memabukkan, tetapi segala sesuatu yang haram seperti babi juga termasuk di dalamnya.

Dalam ilmu hukum, hak-hak manusia dibagi menjadi dua, yaitu hak-hak perseorangan dan hak-hak kebendaan (Subekti, 1992: 63). Hak milik atas air merupakan hak milik kebendaan. Pengertian dan kejelasan mengenai hak milik kebendaan adalah penting. Hal itu ditujukan agar seseorang dapat mengembangkan apa yang dimilikinya, sekaligus mengarahkan seseorang menghargai atau menghormati barang yang menjadi miliknya. Islam melarang adanya sikap tabdzir.

Dalam kajian komparasi teori kepemilikan, benda dalam Islam sangat berbeda dengan kepemilikan yang diusung oleh sistem ekonomi kapitalis dan sosialis. Baqr as-Shadr dalam Iqtiṣādunā menjelaskan setidaknya terdapat tiga poin dalam konsep kepemilikan kebendaan dalam Islam. Pertama, Islam mengakui adanya multiownership (kepemilikan pribadi/individu, negara, dan bersama) (Triono, 2012: 317-338). Kedua, kebebasan ekonomi yang terpola oleh syariah. Hal ini disandarkan pada kaiha mu'āmalah, yaitu "prinsip dasar aktivitas ekonomi (mu'āmalah) adalah kebolehan, sampai terdapat dalil yang menyelisihinya." Ketiga, tanggung jawab sosial (social justice). Setiap benda yang dimiliki oleh manusia atas upaya yang telah dilakukannya terdapat hak orang lain atas benda tersebut (as-Shadr, T.T: 389-699).

\section{Air dan MAQĀSHID AsY-SYaRI'AH}

Urgensi air dalam peradaban manusia di muka bumi bertumpu pada pemanfaatannya. Selama air yang ada pada suatu daerah dapat dimanfaatkan untuk kemaslahatan, di sanalah keberadaan air sudah sesuai dengan fitrah penciptaannya (Abdullah, 2011: 94). Sejalan dengan hal tersebut, pengelolaan dan pemanfaatan air erat kaitannya dengan tujuan-tujuan syariah (maqāṣid alsyari' 'ah). Imam Syātibì menjelaskan hal tersebut secara khusus, sistematis, dan jelas. Secara tegas, ia menyatakan bahwa tujuan utama Allah menurunkan syariah Islam adalah untuk mewujudkan kemaslahatan manusia, baik dunia maupun akhirat (Fauzi, 2012: 141). 
Maṣlaḥah dilihat dari sumber hukum Islam terbagi menjadi dua, yaitu maṣlạ̣ah al-manșūṣah dan maṣlaḥah al-mustanbațah. Maṣlaḥah al-manșūṣah adalah maṣlahah yang secara jelas disebutkan dalam naṣ. Maṣlạ̣ah almustanbatah merupakan maslahat yang dirumuskan oleh pihak-pihak yang kompeten dalam menentukan maslahat. Dari segi sifatnya, maslahat juga terbagi menjadi dua bagian, yaitu maṣlaḥah al-khāṣ̦ah dan maṣlaḥah al-'ammah. Maṣlaḥah al-khāṣ̦ah adalah maslahat bersifat individual, dan maṣlaḥah al'āmmah adalah maslahat yang bersifat sosial-objektif (Suntana, 2012: 58).

Kemaslahatan inilah yang mengantarkan dinamisasi air dalam kehidupan sosial. Dinamisasi ini diartikan sebagai perubahan-perubahan nilai guna air. Pandangan dari teolog al-As'ariyyah dan Maturidiyyah menegaskan hal yang serupa tentang sifat alami air. Golongan ini menyebutkan air sebagai benda alami yang memiliki ketersambungan dengan alam, jumlahnya terbatas, berubah dari satu keadaan ke keadaan yang lain, mengalami kerusakan bentuk, dan mengalami kemusnahan.

Dinamisasi yang terfokus pada perpindahan nilai air dewasa ini dapat terlihat. Namun demikian, pergerakan tersebut lebih mengarah pada air dari sudut pandang ekonomi. Pergeseran air dari makhluk (baca: benda ciptaan) yang bebas menjadi benda terikat dengan syarat ekonomis. Dalam tinjauan fikih, masih memungkinkan menggunakan kaidah al-maṣlaḥah al-'āmmah muqaddamatun 'alā mașlaḥah al-khāṣṣah. Dapat dikatakan bahwa kemaslahat an sosial-objektif lebih dikedepankan untuk suatu kebijakan. Kemaslahatan 'āmmah' dijadikan sebagai barometer keadilan.

Penegasan atas pokok bahasan kali ini adalah keterkaitan air dengan kondisi sosial masyarakat. Kehidupan sosial masyarakat yang sangat plural dan sangat dinamis sesuai dengan perubahan zaman yang dibarengi dengan perkembangan pemikiran dan teknologi tidak menutup kemungkinan akan sangat berpengaruh dengan sepak terjang air di bumi. Kompleksitas masalah yang dihadapi tiap-tiap daerah memberikan warna dan kejelasan di mana dan seperti apa air diposisikan dalam kehiduppan mereka. Sebagai contoh, air menjadi barang berharga bagi para musafir di gurun pasir, bahkan dapat diperjualbelikan. Contoh lain, air merupakan benda biasa namun memiliki posisi penting bagi kehidupan sekelompok orang di pedesaan yang persediaan airnya cukup. Begitu juga air dapat dijadikan benda berharga sebagai sarana ibadah bagi umat muslim ketika menjalankan ibadah haji. 


\section{Al-MiYĀH Al-IQtișĀDIYyah, Respon Air atas Kebutuhan SOSIAL}

Hampir semua ulama fikih klasik menempatkan air sebagai sarana peribadatan (al-miyāh al-diniyyah). Pada fitrahnya, air merupakan makhluk yang multifungsi. Hampir semua aspek kehidupan membut uhkan air. Para ahli biologi menyampaikan bahwa kehidupan di bumi ini dikarenakan adanya keunikan dan kemanfaatan air. Dari fitrahnya, air merupakan zat istimewa. Selain dapat mengantarkan arus listrik, air juga sebagai media dalam menciptakan reaksi kimia. Pada zaman Rasulullah, air menjadi salah satu media obat. Keajaiban tersebut terungkap secara ilmiah setelah Emoto menemukan kristal-kristal air yang berubah menjadi sangat indah setelah dibacakan "bismillah" atau ayatayat al-Qur'an. Sebagai al-miyāh al-fițrah, air ditempatkan sebagai benda ciptaan Allah yang merangkum (setidaknya dibutuhkan) bagi seluruh seluruh aspek kehidupan. Artinya, nilai guna air adalah universal.

Dengan datangnya Islam, mulailah air digunakan sebagai sarana ibadah (almiyāh al-diniyyah). Dalam kajian ini, air tidak diartikan sebagai goods. Implikasi logis dari pengertian tersebut adalah air tidak memiliki unsur kepemilikan, penguasaan, atau pengalihan hak. Dikatakan sebagai benda sarana ibadah karena air merupakan benda utama (pokok) yang mengantarkan seseorang masuk pada aktivitas peribadatan (ritual). Terkait dengan air sebagai benda sarana beribadah, agama-agama di dunia menjadikannya sebagai benda berdimensi ritus. Air juga merupakan sarana penyembuhan penyakit melalui aktivitas ritual, seperti dalam praktik ruqyah (Suntana, 2012: 128).

Setelah itu air memiliki dimensi lain, yaitu air sebagai benda sosial (almiyāh al-ijtimā'iyyah). Di sini, posisi air berkebalikan dengan sebelumnya, yaitu al-miyāh al-dīniyyah. Air ditempatkan sebagai barang (goods). Konsekuensinya adalah ia dapat dipindah haknya, dapat dikelola sesuai dengan kemampuan, terdapat unsur penguasaan, serta air memiliki pemilik. Meskipun demikian, teori ini lebih menekankan pada karakter air yang open access atau terbuka untuk umum.

Secara normatif, pernyataan di atas ditegaskan Allah dalam Q.S.16:10, yaitu:

"Dia-lah, yang telah menurunkan air hujan dari langit untuk kamu, sebahagiannya menjadi minuman dan sebahagiannya (menyuburkan) tumbuh-tumbuhan, yang pada (tempat tumbuhnya) kamu menggembalakan ternakmu”. 
Sebagian ulama hukum Islam berpendapat keberadaan air sebagai benda sosial sangat bergantung pada status tanah tempat air itu berada. Air yang terdapat di lahan seseorang tidak dapat dikatakan sebagai benda sosial secara mutlak. Namun demikian, penerima amanat (yang punya lahan) harus memperhatikan pesan moral Islam tentang adanya hak orang lain yang ada pada kita. Hemat penulis, hak yang dimaksud adalah hak sekadar menghilangkan rasa haus (ḥaqq al-syarāb).

Setelah memahami air sebagai sarana peribadatan (al-miyāh al-dìniyyah), benda sosial (al-miyāh al-ijtimā'iyyah). Kini, air bermetamorfosis dalam hal pengembangan nilai guna dan manfaat. Kompleksitas dari proses ekonomi seperti produksi, distribusi, dan konsumsi mungkin menjadi penghambat ekonom atau ulama klasik untuk tidak membahas air dari segi proses produksi tersebut. Dimensi al-miyāh al-iqtiṣādiyyah tidak sepopuler dimensi air yang lainnya.

Al-Zuhaylī (2002: 4667) merupakan salah seorang ulama yang turut mengkonsepkannya. Konsep ini menjelaskan air dapat digunakan untuk kegiatan-kegiatan komersial (menunjang perekonomian), termasuk untuk diperjualbelikan. Fenomena nyata adalah adanya air kemasan komersial. Kemunculan al-miyāh al-iqtiṣādiyyah ini dikuatkan dengan adanya pertimbangan maslahat dan sadz al-dzarī'ah.

Pergeseran nilai guna dan kedudukan air ini awalnya merupakan hal yang sangat tabu. Namun demikian, perlahan-lahan mulai dapat diterima oleh masyarakat. Fenomena ini menggeser pandangan bahwa air bukan saja benda sosial, melainkan air menjadi benda yang bernilai ekonomi dan membutuhkan kompensasi untuk memperolehnya. Al-miyāh al-iqtiṣādiyyah disandarkan dengan adanya kaidah li al-jalib al-ḍaman atau penerima manfaat harus berbayar. Artinya, setiap orang yang mendapatkan pelayanan harus membayar sejumlah biaya atas pelayanan yang diperolehnya (Suntana, 2012: 132).

\section{E. Simpulan}

Dari pembahasan, dapat disimpulkan beberapa hal sebagai berikut: Pertama, air adalah benda milik Allah secara mutlak, dan manusia juga memiliki hak at as air dengan hak nisbi. Kedua, air merupakan benda yang dapat bertransformasi menyesuaikan kondisi suatu tempat. Selain itu, air sebagai ciptaan Allah memiliki nilai guna universal yang menarik, yakni berkaitan dengan respon air terhadap perubahan sosial, baik atas dasar dinamisasi kebutuhan sosial maupun pergeseran pemikiran masyarakatnya. Air merespon manusia dengan mendedikasikan kedudukannya sebagai benda sosial (al-miyāh al-ijtimā'iyyah). 
Ketiga, sepanjang perubahan fungsi atau nilai dari air mengandung kemaslahatan, baik fardiyyah maupun 'āmmah, maka transformasi tersebut dipandang perlu. Air diistilahkan dengan al-miyah al-fitrah dan meningkat pada level yang lebih khusus, yaitu air dipergunakan sebagai sarana ibadah (al-miyāh aldinniyyah). Keempat, dengan kompleksit as proses ekonomi, yang dibarengi dengan kebutuhan alam terhadap air memunculkan konsep baru, yaitu air sebagai media komersil atau dalam makalah ini disebut dengan al-miyāh aliqtiṣādiyyah. Transformasi air tersebut tidak lepas dari tujuan syariah, yaitu mencapai kemaslahatan dan menghindarkan pada kemudaratan (sad aldzari'ah).

\section{Daftar Pustaka}

Abdullah, Mudhofir. 2011. Masail al-Fiqhiyyah: Isu-isu Fikih Kontemporer. Yogyakarta: Teras.

as-Shadr, Muhammad Baqr. T.T. Iqtiṣādunā. Teheran: Muassasah Dār al-Kitāb al-Islamī.

al-Syātibīi, Ibrāhīm Ibn Mūsā. T.T. Al-Muwāfaqāt Juz 2. Beyrūt: Dār al-Ma'rifat. al-Zuhayli, Waḥbah. 2002. Al-Fiqh al-Islāmì wa 'Adillatuhu. Beyrūt: Dār alFikr.

“Air Sumber Kehidupan dalam Al-Qur'an”, www.kucoba.com diakses pada 15 Januari 2011.

Ensiklopedi Grolier. Ilmu Pengetahuan Populer, jilid 4, hlm. 35, Answer.com. diakses pada 15 Januari 2011.

Fauzi, Yuslam. 2012. Memaknai Kerja. Jakarta: Mizan.

Muhammad dan Alimin. 2004. Etika dan Perlindungan Konsumen dalam Ekonomi Islam. Yogyakarta: BPFE Yogyakarta.

Subekti. 1992. Pokok-pokok Hukum Perdata. Jakarta: Intermasa.

Suntana, Ija. 2010. Politik Ekonomi Islam Siyasah Maliyah: Teori-teori Pengelolaan Sumber Daya Alam, Hukum Pengairan Islam, dan Undang-undang Sumber Daya Air di Indonesia. Bandung: Pustaka Setia.

Triono, Dwi Condro. 2010. Ekonomi Islam Madzhab Hamfara Jilid I: Falsafah Ekonomi Islam. T.T.P.: Irtikaz. 